\title{
Payeses, tenderos y párrocos. El centro-derecha mallorquinista (1899-1983) ${ }^{1}$
}

Peasant Farmers, Grocers and Parish Priests. The Majorcan Regionalist Center-Right (1899-1983)

\begin{abstract}
Joan-Pau Jordà-Sánchez joanpaujordal@hotmail.com

Fundació Gabinet d'Estudis Socials, Illes Balears (GADESO) Centre d'Estudis Demogràfics; Universitat Autònoma de Barcelona (CED) Centro de Administração e Políticas Públicas - Instituto Superior de Ciências Sociais e Políticas, Universidade de Lisboa (CAPP-ISCSP)

ORCID: 0000-0003-4932-7867
\end{abstract}

Recibido: 29-5-2017

Aceptado: 28-7-2017

Cómo citar este artículo / Citation: JORDÀ-SÁNCHEZ, Joan-Pau (2017). Payeses, tenderos y párrocos. El centro-derecha mallorquinista (1899-1983). Pasado y Memoria. Revista de Historia Contemporánea, 16, pp. 177-205.

https://doi.org/10.14198/PASADO2017.16.08

\section{Resumen}

El presente trabajo tiene el objetivo de analizar los orígenes, la evolución y el impacto social del mallorquinismo sobre el conjunto de la sociedad isleña, focalizándose especialmente en las organizaciones y entidades de centro-derecha desde sus orígenes, en la Renaixença, hasta las primeras elecciones autonómicas en 1983. En el caso balear son pocos los trabajos que abordan esta temática y siempre de forma tangencial. Para llevar a cabo este estudio se ha aplicado una metodología mixta: se ha combinado la recolección de fuentes secundarias que se encontraban dispersas en diversas publicaciones con el análisis de la prensa de la época.

Palabras clave: Mallorquinismo, Nacionalismo, Islas Baleares, Transición española, Centro-derecha político, Siglo XX.

${ }^{1}$ Quiero agradecer los comentarios y sugerencias de Gabriel Mayol y Joan Colom en la elaboración de este trabajo, así como el maestrazgo del prof. Antoni Marimon. 


\begin{abstract}
This essay is aimed at analyzing the origins, evolution and social impact of Majorcan regionalism on Majorcan people as a whole. It mainly focuses on center-right organizations from their origin in the $19^{\text {th }}$ century until the first regional elections in 1983. Studies addressing this issue with reference to the Balearic Islands are scarce and always tangential. For this study a mixed methodology has been applied combining secondary sources, gathered from a variety of dispersed publications, and the periodical press of the time.
\end{abstract}

Keywords: Majorcan Regionalism, Nationalism, Balearic Islands, Spanish Transition, Center-Right Politics, $20^{\text {th }}$ Century.

La investigación que aquí se presenta busca analizar los orígenes, evolución e impacto social del mallorquinismo de centro-derecha sobre el conjunto de la sociedad isleña, focalizándose especialmente en sus organizaciones y entidades más representativas. ${ }^{2}$ De esta forma el estudio busca desgranar que ha significado el mallorquinismo conservador para la isla, cual ha sido su capacidad de influencia, que relaciones ha tenido con el resto de territorios de habla catalana y qué nos ha llegado de este movimiento hasta nuestros días. Asumiremos así como hipótesis inicial la idea planteada por Marimon (2003; 2008) de que el mallorquinismo ha sido una ideología que, sin ser mayoritaria en Baleares, ha condicionado profundamente su evolución histórica reciente.

Esta investigación comprende desde la gestación de este movimiento a mediados del siglo XIX hasta la constitución del primer gobierno autonómico, en 1983. También analiza los primeros posicionamientos teóricos regionalistas, que surgen a partir de la publicación de La Qüestió Regional (1899) de Miquel dels Sants Oliver. Esta cronología ha sido escogida porqué permite obtener una visión de conjunto del fenómeno, desde sus orígenes hasta nuestros días.

Ha de ser destacado que para el caso balear son pocos los trabajos que han abordado este tema, siempre de forma tangencial. Nos referimos a obras como las de Josep Melià (1977), Gregori Mir (1988; 1990) o Antoni Marimon (2003; 2006). Así este artículo se enmarcaría en el seno de la historia política, siguiendo las líneas de investigación de autores de reconocido prestigio como De Pablo (1999) o Olazábal (2014) para el caso vasco, o Riquer (1977; 2001), con su ya clásica obra sobre la Lliga Regionalista catalana.

${ }^{2}$ Aceptando las limitaciones del término, en esta investigación se situarán dentro de esta definición primero a aquellas personas, entidades y organizaciones que así se definan y segundo, por su propia evolución histórica, a ideologías como el conservadurismo en sus diferentes acepciones y el carlismo. También situamos en el espectro del centro político buena parte de las personalidades defensoras del liberalismo económico, así como a la democracia cristiana. Sobre las limitaciones y características del concepto de "centro-derecha" ver Bobio (2000). 
Pero, ¿qué es el mallorquinismo? Apropiándonos de la definición que realiza Antoni Marimon (2006: 105), podemos decir que es una ideología, sentimiento o actitud política que da una importancia primordial a Mallorca o algún aspecto de su historia y su cultura. Es un proyecto estrictamente insular, que ha de diferenciarse -pese a las similitudes- del regionalismo y/o nacionalismo que puede darse en Menorca, Ibiza y Formentera. El mallorquinismo puede oscilar desde un sentimiento difuso de apego a la isla, hasta identificar el archipiélago como parte integrante de la nación catalana. En este caso, es sinónimo de catalanismo. Existen términos hermanos al de mallorquinismo que han sido recurrentemente utilizados a lo largo de la historia, y que por eso han de ser explicados. Nos referimos a conceptos como regionalismo y autonomismo. El primero denominaría a aquella doctrina política y social consistente en favorecer, dentro de un mismo estado, el papel de los agrupamientos regionales fruto de la geografía y la evolución histórica y cultural. El segundo, corresponde a aquel posicionamiento que defiende la autonomía política para un territorio.

La metodología utilizada en esta investigación ha sido mixta. Por un lado, se ha procedido a recopilar fuentes secundarias, que se encontraban muy dispersas en diversas obras y publicaciones. Por otro, se ha recurrido al análisis de la prensa escrita de la época. Han sido vaciadas revistas y periódicos disponibles en la Biblioteca de Prensa Histórica del Ministerio de Educación, Cultura y Deporte (http://prensahistorica.mcu.es) como La Palma (1840-1841), La Roqueta (1901-1905), La tarde: diario independiente, de noticias y avisos (1902-1906), Ca Nostra (1907-1914), La Veu d'Inca (1915-1918), La Nostra Parla (1916-1925) o La Nostra Terra (1928-1936). Por último, se ha procedido a consultar las hemerotecas de grandes periódicos del momento, como el ABC (1903-1983), La Vanguardia (1881-1983), El País (1976-1983), La Última Hora (1893-1983) y Diario de Mallorca (1953-1983). Para los procesos electorales, se ha recurrido al archivo histórico digital del Ministerio del Interior de España (www.infoelectoral.mir.es).

\section{Las raíces (1840-1899)}

Diferentes factores históricos, sociales y culturales condicionaron el surgimiento del mallorquinismo político a finales del siglo XIX. El primero de éstos fue la Renaixença, un movimiento cultural de raíz romántica surgido en los territorios de habla catalana y que tiene sus orígenes en la publicación de Oda a la Pàtria (1833) del barcelonés Carles Aribau. La Renaixença se fraguó en la isla a partir del surgimiento de la revista La Palma (1840-1841) (Marimon; Carrió, 2006). Pese al interés por la cultura propia, la tradición y el folklore, su impac- 
to en el seno de la sociedad mallorquina fue escaso. Sin embargo, supuso poner las bases a partir de las cuales surgirían en Mallorca, décadas después, grandes autores en catalán. Además fue también la primera reivindicación social de la identidad singular isleña desde el Decreto de Nueva Planta (1715). Este movimiento, en las islas, de igual forma que en el País Valenciano y a diferencia de Catalunya, fue eminentemente cultural y alejado de cualquier reivindicación nacional. Esto se debería al carácter eminentemente conservador de sus principales figuras, como Josep Maria Quadrado (1819-1896) o Marià Aguiló (18251897), y a la falta de un proceso industrializador como el acaecido en el área de Barcelona (Sorribas, 1989).

Otro elemento que condicionó la evolución del mallorquinismo durante el siglo XIX fue el Carlismo. Esta ideología propugna, desde el tradicionalismo y un catolicismo conservador, una oposición al liberalismo. Pretende restaurar en el trono a los descendientes de Carlos Maria Isidro (1788-1855) volviendo a los principios absolutistas del Antiguo Régimen. En España este movimiento se nutrió de aquellos estamentos perjudicados por las reformas económicas y políticas liberales: la iglesia católica, sectores menestrales y populares rurales y parte de la aristocracia, teniendo mayor aceptación en los territorios Vasco-Navarros y de la antigua Corona de Aragón (Vallverdú, 2014). El carlismo reivindica el sistema de la Monarquía Compuesta Hispánica, defendiendo la vuelta de los antiguos fueros. Sin embargo, autores como FerrerFlórez (2002) destacan que la demanda de la restitución de las instituciones forales no debió ser un elemento central del discurso carlista isleño, distanciándose de esta reivindicación durante la segunda mitad del siglo XIX. Así, hacia 1930, este movimiento se escoró definitivamente hacia posturas alejadas de cualquier autonomismo de corte foral.

El máximo ejemplo de la relación entre el carlismo y el mallorquinismo la encontramos en la figura de mosén Antoni M ${ }^{a}$ Alcover (1862-1932), escritor, folklorista y lingüista. De familia rural y carlista, se ordenó sacerdote en 1886 , interesándose por la literatura y el folklore desde muy joven, primero en castellano y después, desde 1879, decididamente en catalán. Es conocido entre otras cosas, por ser uno de los promotores del I Congrés Internacional de la Llengua Catalana (1906), ser impulsor del Diccionari Català-Valencià-Balear (1962) y ser el primer presidente de la Sección Filológica del Institut d'Estudis Catalans (1911). Ferviente antiliberal y anti-obrerista, fue un firme defensor de las prebendas de la iglesia. En un principio se posicionó abiertamente a favor del carlismo más intransigente para, poco a poco, ir evolucionando hacia posturas regionalistas, llegando a apoyar la primera candidatura electoral de estas características en Baleares, l'Espurna, que se presentó a las elecciones municipales del año 1909 (Mas, 2009). 


\section{La gestación del mallorquinismo}

Pese a los antecedentes citados, no es hasta finales del siglo XIX que surgen en Baleares los primeros posicionamientos regionalistas, tanto a derecha como a izquierda. Así, hacia 1900 se da una cierta efervescencia cultural de la mano de movimientos como el Modernisme y la Escola Mallorquina, que poco a poco, desembocaron en acción política (Marimon; Carrió, 2006).

El Modernisme se instaló con fuerza en Catalunya a finales del siglo XIX, asumiendo desde entonces parte del ideario catalanista, llevando a su máxima concreción la voluntad de crear una cultura "nacional" en catalán, comparable a la del resto de países de Europa (Guasch, 1983). Las principales figuras de este movimiento en Mallorca fueron Miquel dels Sants Oliver (18641920), Miquel Costa i Llobera (1854-1922), Joan Alcover (1854-1926), el citado Antoni M ${ }^{a}$ Alcover, Gabriel Alomar (1873-1941) y Benet Pons i Fàbregues (1853-1922). Muchas de estas personalidades se formaron conjuntamente en el Instituto Balear -máximo centro de formación superior de las Islas en ese período- pasando a la Universidad de Barcelona después, donde entraron en contacto con el catalanismo. Esta generación es importante porque, por vez primera, apareció en las islas una clase intelectual con una identidad definida y una voluntad consciente de incidir en la sociedad. Ahora bien, no ha de olvidarse que el impacto en el conjunto de Mallorca del Modernisme fue escaso. Al cabo de un tiempo muchos de los miembros de este movimiento emigraron a Barcelona para mantenerse fieles a sus ideales y a su forma de ser, e incluso, a su vocación personal. Al ser esta una generación de intelectuales urbana y dinámica, los grupos que podían interesarse por sus propuestas en las islas -clases medias comerciantes e industriales- eran muy débiles en una sociedad como la isleña, eminentemente agraria (Pons, 2002).

El segundo de los movimientos citados, la Escola Mallorquina, es como se ha convenido a denominar a los escritores Novecentistas de Mallorca. Éste fue un movimiento cultural, vinculado a las Vanguardias, hegemónico en Catalunya durante los primeros años del siglo XX. Su programa modernizador y catalanista reflejó la literatura y el arte del momento, influyendo en el desarrollo científico y económico de principios de siglo (Bilbeny, 1988). La máxima expresión de este movimiento en Mallorca fue la Revista Mitjorn, publicada en catalán entre los años 1906-1907. Esta publicación fue la plataforma por la que los nuevos escritores mallorquines tomaron el relevo a la generación de modernistas, informando de la vida cultural de la isla y publicando escritos tanto de isleños como de principatinos (Pons, 2002). La influencia social y política de este movimiento, en contraposición a la Renaixença y el Modernisme, fue muy grande. Damià Ferrà-Ponç (1973: 34-35) afirma en este sentido que: 
"El fulminant canvi de signe [de modernisme a noucentisme] -les causes profundes resten inexplicades- troba una expressió patent amb la revista Mitjorn. [...] una publicació inspirada precisament per l'home que serà el mestre, l'apologista i l'arquetipus precís dels nous temps: Miquel Ferrà (18851947). Ell i els altres noucentistes aniran elaborant tot un ideari polític, social i cultural rotundament antiurbà i ruralitzant. Enfront d'una ciutat que acull una aristocràcia parisitària i unes classes mitges enlluernades pel provincialisme, els noucentistes mallorquins es regiran cap a la pagesia com a depositària de la llengua, de la tradició, de la família [...] com a la classe que ha d'acollir el seu domini d'un país futur. Curiosament, mentre feien rotundes afirmacions de voler esdevenir europeus, rebutjaven de fet la dinàmica social, econòmica i cultural de l'Europa moderna. Era una flagrant passa endarrera després de l'aventura modernista. El noucentisme a Mallorca, tot i la seva frustració política -incapacitat de forjar una consciència nacionalista amb ampli suport popular-, aconseguí mantenir el control sobre la cultura de l'illa durant més de mig segle. I bona part del seu llegat ideològic -com hem remarcat en parlar de l'existència o no del Modernisme a l'illa- continua encara ben operatiu. "

\section{Las primeras propuestas (1898-1899)}

El mallorquinismo no toma realmente carta de naturaleza como movimiento socio-político hasta 1898-1899, en el contexto de la Crisis del 98. En esa época Mallorca era, como se ha venido apuntando, una sociedad agrícola, católica, tradicional, caciquil y analfabeta (65\% de los hombres no sabía escribir en 1900), si bien existía una pequeña pero dinámica clase empresarial, vinculada al comercio y a una industria poco capitalizada focalizada en los bienes de consumo. A modo de ejemplo, en 1875 la isla contaba con unos 250.000

3 "El fulminante cambio de signo [de Modernismo a Novecentismo] -las causas profundas quedan inexplicadas- encuentra una expresión patente con la revista Mitjorn. [...] Una publicación inspirada precisamente por el hombre que será el maestro, el apologista y el arquetipo preciso de los nuevos tiempos: Miquel Ferrà (1885 a 1947). Él y los otros novecentistas irán elaborando todo un ideario político, social y cultural rotundamente anti urbano y ruralizante. Frente a una ciudad que acoge una aristocracia parasitaria y unas clases medias deslumbradas por el provincialismo, los novecentistas mallorquines se regirán hacia la agricultura como depositaria de la lengua, de la tradición, de la familia [...] como la clase que debe acoger su dominio de un país futuro. Curiosamente, mientras hacían rotundas afirmaciones de querer convertirse en europeos, rechazaban de hecho la dinámica social, económica y cultural de la Europa moderna. Era un flagrante paso atrás después de la aventura modernista. En novecentismo en Mallorca, a pesar de su frustración política -incapacidad de forjar una conciencia nacionalista con amplio apoyo popular-, consiguió mantener el control sobre la cultura de la isla durante más de medio siglo. Y buena parte de su legado ideológico -como hemos remarcado al hablar de la existencia o no del Modernismo en la isla- continúa todavía bien operativo." 
habitantes y 2,965 talleres que ocupaban a 13,845 trabajadores (Duran; Marimon, 2004).

Con la pérdida de las colonias antillanas, cogió fuerza en España una corriente de opinión que propugnaba la regeneración moral y política del país así como su completa modernización. Este movimiento constataba así los primeros síntomas de agotamiento del turnismo monárquico establecido con la Restauración Borbónica (1874-1931) (Paredes, 2010). En paralelo, ya desde los años 80 del siglo XIX comenzó a tomar forma el nacionalismo vasco, gallego y catalán (Fusi; Niño, 1997). Por ejemplo, en 1880 tenía lugar el Primer Congrés Catalanista; en 1882 se fundaba el Centre Català; y en 1885 y 1895 se publicaban el Memorial de Greuges y las Bases de Manresa. Este movimiento surgía, a grandes rasgos, para promover la defensa de la lengua e idiosincrasia catalanas frente al españolismo centralista, así como para defender los intereses económicos y sociales de buena parte de la burguesía y las clases medias principatinas (Termes, 2000).

Es en este contexto cuando en 1898 se funda el Centre Regionalista, una asociación promovida por miembros del Partit Republicà Federal de Mallorca (PRFM) como Lluis Martí (1856-1922). El republicanismo federal tuvo cierta implantación en la isla, llegando a contar con presencial municipal, especialmente en Palma, dónde ostentó la alcaldía diversos mandatos. Este partido aunaba a los sectores más dinámicos de comerciantes, industriales y profesionales liberales, así como a una parte de las clases populares. Contó con publicaciones, casinos y centros sociales y, sobre todo, con una militancia activa que se movilizaba en manifestaciones y actos (Marimon, 2008). Hacia 1934 este movimiento se vio reforzado con la creación de Esquerra Republicana Balear, filial local de la Izquierda Republicana de Azaña, que generó unas dinámicas en defensa y promoción de la lengua propia de balares de la mano de figuras como el último alcalde republicano de Palma, fusilado por el Franquismo, el médico, humanista e higienista, Emili Darder (1895-1937).

El Centre Regionalista, similar al citado Centre Català y a la entidad valencianista València Nova (1904-1907), planteó la primera propuesta política nacionalista para Mallorca. Promovió la autonomía municipal, la oficialidad del catalán, la descentralización del estado, la regeneración política y la solidaridad con Catalunya y el País Valenciano. Los sectores más moderados de la organización apoyaron los proyectos descentralizadores del gobierno SilvelaPolavieja (1899) y en 1900 el Centre apoyó a la Unión Republicana, que adoptó en parte sus principios. Sin embargo, poco a poco el Centre fue languideciendo hasta quedar inactivo hacia finales de la década (Serra, 1980). 
Hacia 1898 también ocurrieron cambios en el seno de la iglesia. Ese año tomó posesión de su cargo el Obispo Joan Campins (1859-1915) quién fue responsable de la Diócesis de Mallorca por más de veinte años. Este clérigo promovió, desde posiciones moderadas y católicas, el arraigamiento de la iglesia en la cultura y lenguas propias de las islas, implantando, por ejemplo, la Cátedra de Historia, Lengua y Literatura de Mallorca en el Seminario (Marimon, 2008). Esta labor en Mallorca sería comparable a la realizada coetáneamente por el Obispo de Vic (1899-1916), el catalanista Josep Torres i Bages.

Casi en paralelo, en 1899 se publicó La Qüestió Regional del ya citado Miquel dels Sants Oliver. Esta fue la primera aportación teórica estructurada al movimiento mallorquinista, y es coetánea a trabajos similares como Lo Catalanisme (1886) de Valentí Almirall, La Tradició Catalana (1892) del citado Torras i Bages y De regionalisme i valentinicultura (1902) del valenciano Faustí Barberà (Termes, 2000). Así La Qüestió Regional sería la expresión local de una inquietud intelectual que afectaba a todos los territorios de habla catalana.

Oliver (1868-1920) fue un periodista, historiador e intelectual mallorquín que colaboró desde joven en publicaciones diversas, como El Museo Balear, La Roqueta y participó en la creación del diario La Almudaina, dónde realizó una intensa campaña de propaganda autonomista. En 1904 pasó a residir en Barcelona, dónde trabajaría en el Ateneu Barcelonés, el Diario de Barcelona, y hacia 1909, en La Vanguardia. Firme defensor del Maurismo, intentó ejercer de puente entre éste y el catalanismo conservador.

En La Questió Regional Oliver reconoce los antecedentes particularistas de movimientos anteriores, como la Renaixença, el republicanismo federal y el carlismo, pero no los considera regionalismo. Para él, el regionalismo se fundamentaba en un positivismo orgánico respecto de las realidades regionales de carácter natural e histórico. De esta forma criticará el centralismo y el constitucionalismo abstracto de la Revolución Francesa de 1789 por no respetar estas realidades naturales que conformarían unidades superiores. España estaría formada por varias nacionalidades históricas que coincidirían con los territorios donde se hablaría el castellano, el catalán, el vasco y el gallego. A su vez, habría entidades regionales preexistentes al Estado que tendrían ciertos derechos naturales que se deberían respetar. El regionalismo sería la reivindicación y la defensa de estos derechos. La fórmula que propuso el periodista era un federalismo basado en estas regiones históricas, sin dar importancia al modelo de Estado. En cuanto a Mallorca, ésta encajaría dentro de la nacionalidad catalana junto con el resto de los territorios de la misma lengua. Sin embargo, también consideraba que la isla podría convertirse en una entidad regional propia y separada, porque ya había sido un reino autónomo en el pasado. La dife- 
rencia entre Mallorca y Cataluña radicarían, para Oliver, en que en el Principado la Renaixença habría derivado en una opción política por la contradicción de sus élites ante la política económica del Estado español y en Mallorca no (Jordà et al., 2016).

Sin embargo, ha de remarcarse que pese a la existencia del Centre Regionalista, la influencia del Obispo Campins y la aportación teórica de Oliver, no fue hasta diez años después, en 1909, cuando se presentó por primera vez una opción netamente mallorquinista a unas elecciones: l'Espurna.

\section{L'Espurna (1909)}

L'Espurna se gestó como asociación cultural en el seno de un ciclo de conferencias sobre regionalismo llevado a cabo en el Centre Català de Mallorca en 1909, donde participaron figuras como Antoni Ma Alcover, Benet Pons i Fàbregues o Lluis Martí, entre otros. ${ }^{4}$ A lo largo de estas charlas se fue constatando la conveniencia de crear una organización unitaria de los regionalistas mallorquines, en la línea de la Lliga Regionalista catalana, para llevar a cabo sus ideales. La Lliga era un partido regionalista surgido en 1901 como expresión política del catalanismo moderado, burgués y pactista. Cuando los debates se generaron en el Centre Català, este partido se encontraba en un ciclo de éxitos electorales que le llevaron a controlar la Diputación de Barcelona con Prat de la Riba (1870-1917) como presidente (Riquer, 1977).

Fruto de estas reflexiones surgió la asociación l'Espurna, que a finales de abril decidió participar en las elecciones municipales de Palma con el candidato Antoni Quintana Garau (1884-1935) por el Distrito I (Cort, Sant Nicolau y Santa Eulària), enarbolando la bandera del regionalismo y dejando al margen otras ideologías. Fue el producto de la convergencia entre los sectores del catalanismo cultural (Antoni $\mathrm{M}^{\mathrm{a}}$ Alcover, Joan Alcover, Llorenç Riber...) y de unos sectores regionalistas que no estaban encuadrados en ningún grupo socieconómico, como el propio Antoni Quintana. ${ }^{5}$ La candidatura fue inmediatamente criticada tanto por la derecha españolista como por la izquierda. Los primeros la criticaron por catalanista, los segundos por clerical y antiliberal (Pons, 1978). La formación obtuvo el 13\% de los votos, quedándose lejos de obtener representación en el consistorio palmesano. Pese a todo, esta candidatura fue importante porqué surgió en un contexto de crisis política estatal, a rebufo de los éxitos del catalanismo en el Principado y como una de las consecuencias de la Semana Trágica de Barcelona, de forma similar al proyecto del Centre Regionalista Valencià, en el País Valenciano, de Miquel Duran (1883-

\footnotetext{
${ }^{4}$ Ca Nostra, 10/04/1909 y 24/04/1909.

${ }^{5}$ La Tarde, 29/04/1909.
} 
1947). Por otra parte, algunos de sus miembros tuvieron posteriores actividades políticas, fundando el Centre Regionalista de 1917 o el Centre Autonomista en 1930 (Pons, 1978).

\section{La primavera mallorquinista (1917-1923)}

Entre 1917 y 1923 se produjo una expansión de las organizaciones mallorquinistas (Marimon, 2008). Hay que recordar que en 1914 la Lliga había conseguido su mayor hito político, la creación de la Mancomunitat de Catalunya. Si bien no tenía más que funciones puramente administrativas, esta entidad adquirió gran importancia política porqué fue el reconocimiento por parte del Estado de la personalidad singular de Catalunya des de 1714. Así mismo, en 1917 el jefe de la Lliga en las Cortes, Francesc Cambó (1876-1947), impulsó una fallida Asamblea de Parlamentarios que exigió la autonomía para Catalunya así como profundas reformas sociales y políticas (Riquer, 1977). Durante estos años el sistema de la Restauración entro en una crisis sistémica, primero debido al aumento de los conflictos sociales (Huelgas Generales de 1916, 1917; pistolerismo en Barcelona; miedo por parte de las élites a una revolución como la Rusa...), después por el conflicto militar surgido con la creación de las Juntas de Defensa y la Guerra de Marruecos; y por último, por la expansión en términos relativos de los nacionalismos vasco, gallego y catalán. Todo esto llevó al golpe de estado de Primo de Rivera (1923-1930) (Paredes, 2010). Pese a la inestabilidad, estos años supusieron en Baleares un período de cierto dinamismo económico. Se produjo un crecimiento agrario vinculado a la expansión de la propiedad payesa, a la vez que se desarrollaron nuevos sectores industriales (energía, textil, calzado...). Sin embargo, las islas seguían siendo un territorio conservador, dónde el caciquismo, los partidos del turno dinástico y la iglesia tenían un gran poder (Duran; Marimon, 2004).

En este contexto, en los años 1917 y 1919 el Centre Regionalista de Mallorca fue refundado como entidad política bajo la presidencia de Guillem Forteza (1892-1943) y Joan Estelrich (1896-1958) entre otros. ${ }^{6}$ Este fue el

\footnotetext{
${ }^{6}$ Estelrich fue un escritor y político mallorquín que desarrolló buena parte de su carrera en Catalunya, siendo uno de los dirigentes de la Lliga Regionalista. Con el estallido de la Guerra Civil se pasó al bando franquista, ejerciendo diversos cargos en la Sociedad de Naciones y en la UNESCO. Por otro lado, Guillem Forteza fue un arquitecto y político palmesano que destacó por la elaboración de gran número de escuelas desde 1921 hasta el advenimiento de la II República. En el ámbito político presidió diferentes asociaciones culturales, como el Centre Regionalista de Mallorca (1917-1919) y fue uno de los redactores de La Veu de Mallorca. En 1919 se vinculó al Partido Liberal, dominado en Mallorca por Joan March, llegando a ser alcalde de Palma en 1923. En 1931 escribió Pel ressorgiment polític de Mallorca, una antología de sus escritos regionalistas (Marimon; Carrió, 2003).
} 
primer partido mallorquinista como tal de la historia (Marimon, 2008). Esta formación seguía el modelo de la Lliga y pretendía una autonomía municipal y regional dentro de un Estado ibérico. Supuso la articulación política definitiva de los noucentistes mallorquines, intelectuales de clase media, que editaban La Veu de Mallorca (1917-1918). El Centre Regionalista participó en la candidatura municipal por Palma del Bloc Assembleista de 1917 -una coalición partidaria del proyecto citado de la Asamblea de Parlamentarios- y propugnó la abstención de cara a las elecciones legislativas de 1918 con un manifiesto (40.000 ejemplares). El motivo, según ellos, era la inexistencia de partidos políticos que defendiesen los intereses de los isleños y su imposibilidad de organizar una lista propia. ${ }^{7}$ Durante este período el Centre Regionalista exploró, conjuntamente con otros sectores de la sociedad, la posibilidad de impulsar una Mancomunidad Balear similar a la catalana como forma de descentralizar el Estado, si bien el proyecto no fructificó. ${ }^{8}$

A principios de 1919 esta entidad impulsó una Coalició Mallorquinista, conjuntamente con reformistas y republicanos federales. Sin embargo, al poco tiempo surgieron tensiones entre los sectores más moderados y los partidarios de romper definitivamente con el régimen de la Restauración. Así, los primeros, formados por Guillem Forteza y la mayoría de los miembros de la organización, pasaron a formar parte del Partido Liberal, estableciéndose como una corriente interna dentro de esta formación política, lo que llevó a la disolución definitiva de la entidad. Gracias a eso, Forteza llegó a ser alcalde de Palma en 1923 (Peñarrubia, 1991). Esto sería indicativo de cómo las formaciones de ámbito estatal eran capaces de constituir proyectos suficientemente amplios como para que sectores regionalistas se sintiesen cómodos en ellos.

Otro hito en la historia del mallorquinismo de esos años fue la creación de la Associació per a la Cultura de Mallorca. Esta entidad fue impulsada en 1923 a partir de una proclama firmada por diferentes profesionales liberales e intelectuales de la isla, de los cuales hay que destacar a Joan Capó (18881952), Guillem Colom (1890-1979), Pere Oliver Domenge (1886-1968) y Emili Darder. Fue creada con la intención de convertirse en una plataforma cultural que uniese a las diversas tendencias mallorquinistas para impulsar la cultura propia de la isla y la recuperación de la identidad nacional de Mallorca. ${ }^{9}$ Sin embargo, con la dictadura de Primo de Rivera (1923-1930) la organización redujo mucho su actividad. ${ }^{10}$ Las principales acciones fueron la organización

\footnotetext{
${ }^{7}$ La Veu d'Inca, 09/03/1918.

${ }^{8}$ La Vanguardia, 01/06/2016, 09/06/2018.

${ }^{9}$ La Nostra Parla, 04/1924.

${ }^{10}$ La Vanguardia 10/11/1931.
} 
de conferencias sobre temas científicos, lecturas poéticas, cursos de lengua, historia, arte y arqueología, homenajes a escritores desaparecidos, conmemoraciones... así como la publicación de libros y revistas, como el Almanac de les Lletres o la revista La Nostra Terra (1928-1936). ${ }^{11}$ Esta revista, escrita en catalán, fue un exponente de las directrices estéticas y de pensamiento de la Escola Mallorquina. Otra importante aportación de esta entidad fue la propuesta -infructífera- de Anteproyecto de Estatuto de Autonomía el año 1931 para Mallorca e Ibiza. Contó con delegaciones en Palma, Felanitx, Sóller, Inca, Capdepera, Pollença, Valldemossa y Andratx (Massot-i-Muntaner, 1978). Si bien la Associació per a la Cultura de Mallorca era una organización eminentemente cultural, al ser un proyecto unitario contó con figuras de ideología diversa, entre ellos católicos, conservadores y liberales. ${ }^{12}$

\section{La II República}

El período primorriverista supuso un impasse en la expansión y consolidación de los nacionalismos sin estado en España, tanto de derechas como de izquierdas. Sin embargo, a finales de los años 20, en el contexto de la crisis económica mundial de 1929, la incapacidad de Primo de Rivera para regenerar el sistema de la Restauración y la creciente oposición democrática le llevaron a dimitir en 1930. Alfonso XIII intentó devolver al régimen monárquico a la senda parlamentaria, convocando elecciones municipales en 1931. Estas se celebraron en abril, y los republicanos se hicieron con la mayoría de las capitales de provincia. Ante esto y carente de apoyos, el rey abdicó, proclamándose la II República (Paredes, 2010). En las islas se daba un escenario totalmente opuesto, predominando los sectores conservadores y monárquicos: en las elecciones de Palma los republicanos se habían hecho con 5 regidores, los socialistas con 4 y las fuerzas monárquicas con 27.

Durante este período se reprendió la actividad política mallorquinista con la fundación del Partit Regionalista de Mallorca (PRM) en diciembre de 1930. Esta formación, encabezada por antiguos mauristas moderados, estaba constituida por figuras que, hasta el momento, no se habían posicionado abiertamente por el mallorquinismo político o cultural. Eran pequeños burgueses, sobre todo de industriales, abogados, comerciantes y propietarios. El maurismo -por

${ }^{11}$ La Vanguardia 21/05/1935.

${ }^{12}$ A modo de ejemplo, tres de sus cuatro presidentes, Elvir Sans Rosselló (1923-24), Miquel Massutí Alzamora (1932-33) y Josep Sureda i Blanes (1934-36) -quién fue director de diversas empresas del oligarca isleño Joan March- nunca fueron considerados personalidades hostiles al régimen, pese a su significación el mundo asociativo catalanista. En este sentido, ver el trabajo de Graña (2007). 
su máximo exponente, Antonio Maura (1853-1925) ${ }^{13}$ - era en ese momento una corriente conservadora de ámbito estatal que propugnaba la regeneración política, económica y social del país, desde una óptica tradicional y confesional. El PRM manifestaba en sus estatutos que, sin poner en duda la unidad de España, buscaba reavivar la conciencia mallorquina en sus aspectos históricos, geográficos y culturales como medio para lograr una descentralización administrativa.

En mayo de ese mismo año también se creó el Centre Autonomista. Este tenía un carácter más nacionalista y se encontraba formado en su mayoría por intelectuales y profesionales liberales influenciados por el político catalán regionalista Francesc Cambó. Estaba dirigido por Antoni Salvà i Ripoll (18681949) (Marimon, 2008). ${ }^{14}$

Ambos grupos eran conservadores y católicos, propugnaban la autonomía para las Islas y la lucha contra el caciquismo del empresario Joan March Ordinas (1880-1962). ${ }^{15}$ Por eso crearon un comité mixto de cara a las elecciones municipales de 1931. Éste era el representante insular del Centro Constitucional (CC) impulsado por Cambó a nivel estatal. El CC era, como en Baleares, el resultado de la unión de los mauristas con diversas formaciones regionalistas catalanas, valencianas y gallegas, como la Lliga o la Unió Valencianista Regional (UVR). Buscaba crear así un gran espacio de centro regeneracionista que apuntalase la monarquía parlamentaria. Sin embargo, la proclamación de la II República, la aparición de la CEDA y la consolidación del Partido Radical, frustraron el intento por parte de la Lliga de intervenir en la dirección de la política española. ${ }^{16}$ En Ibiza una escisión del tradicional Partido Liberal, el Partido Liberal Histórico, liderado por Carles Roman (1887-1939) se posicionó en favor de este proyecto, impulsando el Partit Liberal Regionalista d'Eivissa. Sin embargo, ante la nueva coyuntura republicana, éste desapareció al poco tiempo. ${ }^{17}$

En las elecciones municipales de abril, la coalición obtuvo grandes resultados en Mallorca, con regidores en municipios como Alaró, Alcúdia, Binissa-

${ }^{13}$ Antonio Maura y Montaner (1853-1925) fue un político mallorquín, presidente del Consejo de Ministros en cinco ocasiones durante el reinado de Alfonso XIII, máximo exponente dentro del conservadurismo de los partidarios de una regeneración profunda del sistema de la Restauración.

${ }^{14}$ La Nostra Terra, 05/1936.

${ }^{15}$ Joan March Ordinas fue un contrabandista, empresario y financiero, fundador de la Banca March. Su financiación del Golpe de Estado de 1936 contra la república fue clave para el éxito de los golpistas.

${ }^{16}$ La Vanguardia, 06/03/1931 y 07/12/1934.

${ }^{17}$ Diari de Balears, 06/11/2011. 
lem, Bunyola, Calvià, Capdepera, Consell, Esporles, Felanitx, Manacor, Maria, Marratxí, Muro, Palma, Petra, Pollença, Porreres, ses Salines, Santa Eugènia, Santa Maria, Sant Llorenç y Valldemossa. ${ }^{18}$ Sin embargo, ya proclamada la República, en los comicios parciales de mayo de ese mismo año -solo en los ayuntamientos dónde la izquierda impugnó los resultados anteriores- los regionalistas perdieron toda su representación, con la excepción de Binissalem, Sencelles ( 4 , en coalición) y Sineu ( 2 , en coalición), manteniendo cinco electos en Palma. En contraposición, en los comicios municipales parciales de 1933 la formación aumentó su presencia electoral, obteniendo representación en Campanet (1), Costitx (2), Deià (2), Fornalutx (2 en coalición), Lloret (2), Lloseta (1) y Sineu (1). ${ }^{19}$

Pese a los éxitos, la situación de inestabilidad política y social entre los años 1931-1936 en España desdibujó el papel de los regionalistas isleños, que apostaron por participar en diferentes coaliciones de derechas de cara a los comicios generales de 1931, 1933 y 1936. Esto se debe, sobre todo, por el carácter profundamente católico del regionalismo conservador en Mallorca, que ante las tensiones de la República y la polarización social, se alinearon con la iglesia y las fuerzas del orden, como harían sectores próximos a la Lliga en Catalunya. De esta forma el candidato regionalista, el abogado Bartomeu Fons i Jofre de Villegas (1888-1962), fue elegido diputado en diversas ocasiones y, en las Cortes, se incorporó a la minoría de la Lliga Catalana (González y Vilalta, 2006). Fons, máximo líder de las fuerzas regionalistas de centro-derecha, se distinguió por acciones en defensa de la promoción económica de las islas (exploración del cultivo del tabaco, subvenciones a la ganadería, defensa de la protección de la industria del calzado....). ${ }^{20}$ También se significó como un defensor de las políticas sociales desde un punto de vista católico, así como de los privilegios de la Iglesia frente al Estado. ${ }^{21} \mathrm{~A}$ su vez, el PRM participó en el anteproyecto de Estatuto de Autonomía impulsado por la Associació per a la Cultura de Mallorca. El proyecto no fructificó debido a la negativa de los representantes menorquines en participar en él, la poca consciencia regionalista en las islas, los recelos de la izquierda -que tenía miedo que la autonomía cayese en manos

${ }^{18}$ Folleto referente al Anuario Estadístico de 1931 (INE) sobre "Número de concejales proclamados por el artículo 29 de la Ley y elegidos por votación, en las elecciones del 12-4-1931, y filiación política, según datos facilitados por las Juntas." (http://www.ine.es).

${ }^{19}$ Folleto referente al Anuario Estadístico de 1931 (INE) sobre "Resultado de las elecciones de Concejales verificadas en 12 de abril de 1931 en las provincias de España y Posesiones españolas del Norte de África, según datos facilitados por las respectivas Juntas municipales del Censo Electoral" (http://www.ine.es).

${ }^{20}$ La Vanguardia 01/11/1934, El Bien Público 07/03/1934, 07/06/1934 y 07/12/1935.

${ }^{21}$ El Iris 23/06/1931, El Bien Público 04/11/1934. 
de la derecha- la oposición del nacionalismo español y el desinterés de las élites. Ante el fracaso, los regionalistas y los republicanos federales intentaron reimpulsar el debate, otra vez, en 1932 y 1936 (Duran; Marimon, 2004).

Durante estos años hay que destacar también la figura del ya citado escritor y periodista Joan Estelrich. Desde muy joven se involucró en el movimiento regionalista, dirigiendo por ejemplo el Centre Regionalista de Mallorca en 1917. Durante la República obtuvo mayor protagonismo como miembro de la Lliga, desligándose orgánicamente de la política balear. Llegó a ser secretario de Cambó, siendo un referente para los mallorquinistas de centro-derecha al ser elegido diputado por Girona en tres ocasiones. Fue uno de los responsables del "Missatge als Mallorquins", un manifiesto que se publicó en mayo de 1936 con la finalidad de intensificar las relaciones culturales entre Catalunya y Mallorca (Estelrich 2015).

Poco antes de los comicios de febrero de 1936, en un informe sobre la situación política elaborado por Estelrich, se criticaba la falta de acción y propaganda de los regionalistas isleños. Según él, los sectores más autonomistas permanecían inactivos y sólo Bartomeu Fons era valorado positivamente (Estelrich, 2015). Las derechas, en general, eran cada vez más hostiles al catalanismo, a excepción de una minoría de intelectuales, y esto desdibujaba todavía más el papel de los regionalistas mallorquines dentro de las coaliciones conservadoras, especialmente en los meses anteriores al Golpe de Estado de Julio de 1936. En consecuencia, fue en el seno de formaciones de centro-izquierda, como Esquerra Republicana -filial local de la Izquierda Republicana de Azañadónde encontraron un espacio de influencia los regionalistas y nacionalistas. Así, este partido, creado en 1934, aglutinó a los sectores más dinámicos del mallorquinismo, con figuras como los citados Emili Darder o Pere Oliver Domenge (Marimon, 2008).

\section{Los primeros años del Franquismo (1936-1962)}

Una vez que triunfó el golpe de estado en Baleares, en julio de 1936, comenzó la represión de los sectores contrarios a la dictadura. En la isla, fueron asesinadas sumariamente unas 2.000 personas, forzando el exilio de otros miles (Ginard, 2015). En este contexto de represión, la derecha regionalista isleña no sufrió la persecución con tanta dureza como socialistas, comunistas y republicanos. Los partidos políticos mallorquinistas fueron ilegalizados, así como también sus asociaciones y prensa, pero trayectorias de vida como las de Miquel Ferrà, Guillem Colom o Joan Estelrich son el ejemplo de que, pese a su pasado, muchos destacados regionalistas de centro-derecha no sufrieron con severidad la represión, llegando algunos de ellos a participar en mayor o menor 
medida del nuevo régimen dictatorial. A modo de ejemplo, después de la Guerra Civil Miquel Ferrà fue bibliotecario de la Biblioteca Provincial, Guillem Colom siguió como enseñante y Estelrich fue delegado permanente de España en la UNESCO. En contraposición, los republicanos y nacionalistas de izquierdas fueron perseguidos y sus máximos dirigentes asesinados o exiliados. Esta condescendencia hacia el regionalismo puede que tuviese que ver con el apoyo decidido de éstos a las coaliciones conservadoras lideradas por la CEDA en las elecciones legislativas de 1933 y 1936.

Poco después de 1939 empezó a vislumbrarse, desde los sectores más moderados del mallorquinismo, una vuelta a la actividad cultural. Por ejemplo, en el funeral de Guillem Forteza, en 1943, la poetisa Ma Antònia Salvà (18691958) habló de "la patria mallorquina". En 1946 el filólogo e historiador Francesc de Borja Moll (1903-1991) impulsó las primeras ediciones de libros en catalán y en 1947 se retomó el teatro costumbrista en esta lengua. En paralelo, casi sin interrupción, persistió la actividad literaria de l'Escola Mallorquina, siendo durante esa época la producción cultural genuina isleña. A mediados de los años 50 Jordi Pujol (1930), futuro presidente de la Generalitat (1980-2003), intentó establecer contactos con la oposición cristiana más catalanista, infructuosamente (Marimon; Carrió, 2003). En 1961 se creó la comisión del centenario del nacimiento de Antoni $\mathrm{M}^{\mathrm{a}}$ Alcover, y en 1962 se fundó la revista Lluc, vinculada a los misioneros del sagrado corazón, que desde 1968 sería íntegramente en catalán. Los años sesenta son, además, el período en el que el catalán vuelve a las parroquias de las islas (Marimon, 2008).

No hay que olvidar, sin embargo, que la tendencia impuesta y promovida por el régimen dictatorial era el nacional-catolicismo uniformista español. Así, estos avances en la recuperación de cierta producción cultural en catalán han de ser considerados testimoniales y puede que se den, como afirma Pinya (2016), porqué la derecha mallorquina, catalanoparlante y acomodada, había ganado la Guerra Civil y no veía con malos ojos aquellos aspectos más moderados de la Escola Mallorquina.

\section{La recuperación (1962-1975)}

En los años sesenta del siglo pasado una serie de intelectuales y profesionales de clase media de diversas ideologías impulsaron la Obra Cultural Balear (OCB) para promover la cultura propia de Mallorca. Esta entidad surgía en un momento trascendental para la historia de Mallorca, el llamado boom turístico.

El fin del aislamiento del Régimen Franquista, la reconstrucción económica de Europa posterior a la II Guerra Mundial, los bajos salarios y el abaratamiento del transporte aéreo facilitó el florecimiento de la industria turís- 
tica. Así, a lo largo de los años 60 y 70 del siglo pasado la economía balear pasó de ser eminentemente agraria a terciarizarse. En 1960, visitaron las islas 400.000 turistas; en 1973, más de siete millones. La población creció, gracias a la inmigración peninsular. La isla pasó de 443,000 habitantes en 1960 a más de 525,000 en 1973. Núcleos como Palma o Calvià duplicaron o cuadriplicaron su población en ese lapso de tiempo (Duran; Marimon, 2004).

La OCB fue fundada el 31 de diciembre de 1962 en Palma, y entre los socios fundadores se encontraban Guillem Colom (1890-1972), Miquel Forteza Pinya (1888-1969), Miquel Fullana (1905-2000) o el ya citado Francesc de Borja Moll. Algunas de estas figuras, como ya hemos venido apuntado, se situaban ideológicamente en posiciones católicas, liberales y conservadoras (Marimón; Carrió 2003). Esta entidad es actualmente la institución cívica más importante e influyente de baleares en defensa de la promoción de la cultura propia y la normalización lingüística, y sus orígenes son similares a los de su entidad homóloga principatina, Omnium Cultural, creada en año 1961.

El primer presidente de la OCB fue Miquel Forteza, bajo cuyo mandato (1962-69) se iniciaron los cursos de catalán, entonces la actividad principal de la entidad. Desde 1968 la asociación colaboró en la edición de la revista Lluc. Climent Garau (1970-76) le sucedió en la presidencia. Durante su mandato se crearon las delegaciones locales en Menorca, Formentera, así como en multitud de pueblos de la isla. Josep Maria Llompart fue el tercer presidente de la entidad (1976-83), liderándola durante la transición democrática. En este período la OCB tuvo un papel de gran trascendencia para el reconocimiento oficial de la lengua y la cultura catalanas en Baleares. A modo de ejemplo, en 1979 impulsó el movimiento de las Escuelas Mallorquinas y de la enseñanza en catalán y en septiembre organizó las Fiestas Pompeu Fabra en Mallorca con motivo del 750 aniversario de la reconquista de Mallorca.

En paralelo al surgimiento de esta entidad, en 1967 el abogado Josep Melià (1939-2000) publicó Els Mallorquins -que sería reeditado en 1977 con el título La Nació dels Mallorquins (Melià, 1977)- siendo la mayor aportación teórica al nacionalismo isleño en más de treinta años (Pons, 2002). Esta obra puso las bases de un nuevo mallorquinismo, hasta el punto que su influencia -sobre todo en el seno de la izquierda- ha durado hasta nuestros días. La obra de Meliá se editó siguiendo la estela de libros semejantes, como fueron Notícia de Catalunya (1954) de Jaume Vicens Vives y Nosaltres, els valencians (1962) de Joan Fuster. Como en el caso de La Qüestió Regional de Oliver, este ensayo era la expresión mallorquina de una inquietud intelectual que afectaba también a Catalunya y el País Valenciano. 
Para Melià, el pueblo mallorquín habría nacido con la conquista de Jaime I en 1229 y tendría la lengua catalana como idioma propio. Después, a lo largo de los siglos, se habría formado una personalidad singular de Mallorca (y por extensión también en el resto de islas) que habría entrado en profunda decadencia a partir de 1715 con la desaparición de las instituciones forales y la implantación del Decreto de Nueva Planta. Al mismo tiempo, las contradicciones internas de la sociedad mallorquina, el aislamiento, el individualismo y la marginalidad histórica habrían sido factores que habrían impedido la aparición de proyectos colectivos en la isla. A pesar de todo, el autor considera que a partir del siglo XIX aparece un movimiento de recuperación de la lengua por parte de los intelectuales, si bien este no conecta con la mayoría población, debido, sobre todo, de la poca instrucción de los habitantes de la isla y de la progresiva castellanización de la élite burguesa. Durante los años posteriores a la Guerra Civil la castellanización se habría agravado por la decisión de las familias de la clase ociosa de Mallorca de educar a sus hijos en castellano, así como por la llegada en masa de población procedente de Castilla, Andalucía o Extremadura atraída por el boom turístico. Para solucionar esta situación, que el autor considera de crisis, se propone recuperar el prestigio de la lengua catalana, superar el desconocimiento entre las islas del archipiélago, encontrar una solución original al modelo insular y recobrar los lazos con el resto de los Países Catalanes (Jordà et. al., 2016).

\section{La Transición y el surgimiento de Unió Mallorquina (UM) (1975-1983)}

En 1974, con un discurso mallorquinista y aperturista, Josep Melià fue elegido procurador por el Tercio Familiar de las Cortes Franquistas, gracias sobre todo, al gran apoyo de la ruralía isleña. Pocos meses después, el 20 de noviembre de 1975 moría Franco. Se iniciaba una nueva etapa en España: la Transición a la democracia. En Baleares una abrumadora mayoría de la población apoyó las reformas aperturistas del gobierno, mostrando la oposición democrática mayor debilidad que en otras regiones, como Madrid o Barcelona. Así los partidarios de la Ruptura eran residuales en un territorio que, pese haber sufrido profundos cambios con la introducción del turismo de masas, seguía siendo mayoritariamente conservador (Duran; Marimon, 2004).

En este marco, la derecha mallorquinista, de la mano de Melià se empezó a organizar políticamente para incidir en el nuevo escenario político. Así, en diciembre de 1976 se presentó el Partit Nacionalista Mallorquí (PNM), una formación de centro-izquierda que buscaba la autonomía para Baleares, así como promover una economía mixta, más equilibrada y respetuosa con el campo ma- 
llorquín. ${ }^{22}$ Este partido tenía fuertes paralelismos con la Convergència Democràtica de Catalunya (CDC) de Pujol, creado en 1974. CDC buscaba "fer país" entendido como la promoción de una determinada moral en favor de una colectividad catalana, la democracia y la autonomía (Amat, 2014).

En paralelo, se constituyó el perqueño Grup Autonomista i Socialista de les Illes (GASI). Liderado por Climent Garau, ${ }^{23}$ esta formación era más izquierdista y nacionalista que el partido de Melià. Una parte de esta organización convergió con el PNM, disidentes del Partit Socialista de les Illes (PSI, futuro PSM, Partit Socialista de Mallorca) e independientes, para impulsar la Aliança Nacional Mallorquina (ANAM).

En su programa la ANAM reclamaba un marco de libertades democráticas y un Estatuto de Autonomía, y apoyó el Referéndum para la Ley de Reforma Política, que en Baleares obtuvo el 95\% de los votos afirmativos con un 89\% de participación. Al año siguiente, la ANAM se disolvió para impulsar la Unió Autonomista (UA), referente del nacionalismo centrista en Baleares. Esta formación competiría por el espacio autonomista e insularista político con el PSI, que se presentaba en coalición con el Partido Socialista Popular de Tierno Galván (Adan; Payeras, 2015) y en menor medida, con la Unión Democrática de las Islas Baleares (UDIB). La UDIB era un partido democristiano cercano al Equipo de la Democracia Cristiana de Joaquín Ruiz-Giménez (1913-2009) sensible a las ideas del mallorquinismo político. Sin embargo, su fracaso electoral hizo que acabase integrándose en la UCD de Adolfo Suárez. El PSI en cambio, es un partido nacionalista y ecologista de centro-izquierda fundado en 1976. Esta formación ha conseguido cierta presencia en las islas (entre el 7\%$15 \%$ de los votos) siendo el principal partido mallorquinista hasta hoy en día.

Poco antes de las elecciones a Cortes de 1977 -las primeras democráticas en casi cuarenta años- las fuerzas políticas de Baleares se reunieron en la Fundación Dragan de Palma a instancias del PSI. En esta reunión se acordó que los candidatos elegidos al Congreso y el Senado por Baleares lucharían por la Autonomía, independientemente de su afiliación. El pacto fue firmado por el PSOE, UCD, PSI, PCE, UDIB, Frente Democrático de Izquierdas (FDI), Partido

22 El País, 21/12/1976.

${ }^{23}$ Climent Garau Arbona (Palma de Mallorca, 1924-Palma de Mallorca, 2015) fue un farmacéutico y político mallorquín. Fue presidente de la Obra Cultural Balear desde 1970 hasta 1976. En 1975 fundó el partido Aliança Nacional Mallorquina (ANAM) y, al año siguiente, el Grup Autonomista i Socialista de les Illes. Posteriormente se incorporó al Partit Nacionalista Mallorquí y a la Unió Autonomista de Balears, de la que fue candidato a las elecciones generales del año 1977. Finalmente, se afilió al Partit Socialista de Mallorca, por el que también se presentó a las elecciones generales del año 1982. En ninguna de las dos ocasiones salió elegido. En 1985 fundó el Grup Blanquerna, una entidad dedicada al estudio de la realidad cultural y nacional de Mallorca. 
Carlista y Movimiento Comunista de las Islas Baleares (MCIB) y a título individual, por Abel Matutes. Esto afectó sustancialmente las aspiraciones de la UA, que vio como la reivindicación autonomista, aunque fuese solo de manera formal, fue asumida de forma transversal por todo el espectro político balear. ${ }^{24}$

La UA presentó como candidato a Josep Melià, todavía Procurador en Cortes, y realizó 64 actos. A modo de ejemplo de la capacidad financiera de este partido, éste dispuso de 21 páginas de publicidad, muy por detrás de la UCD, AP o el PSOE (Adán; Payeras, 2015). Los resultados para los autonomistas fueron bastante modestos: 11.846 votos (3,70\%). De éstos, casi todos en Mallorca. En Palma, la formación obtuvo únicamente el 2.21\% de los sufragios, y solo en algunos municipios del interior de Mallorca obtuvo resultados significativos, como Algaida (14.74\%), Artà (17.7\%) Petra (21.8\%), Sant Llorenç des Cardessar (16.8\%) y Sineu (22.4\%) 25 (Tabla 1).

\section{Tabla 1. Resultados elecciones al Congreso de los Diputados} en Mallorca $(1977)^{26}$

\begin{tabular}{c|c|c|c}
\hline Partido & Voto & $\%$ & Diputados \\
\hline UCD & 140651 & 52.0 & 4 \\
\hline PSOE & 67750 & 25.0 & 2 \\
\hline AP & 19545 & 7.2 & \\
\hline PSP-US & 10704 & 4.0 & \\
\hline PCIB & 11241 & 4.2 & \\
\hline UAB & 11348 & 4.2 & \\
\hline UDIB & 4670 & 1.7 & \\
\hline FDI & 1294 & 0.5 & \\
\hline RES & 1544 & 0.6 & \\
\hline AET & 1042 & 0.4 & \\
\hline CJA & 911 & 0.3 & \\
\hline
\end{tabular}

Fuente: www.infoelectoral.mir.es

${ }^{24}$ Diario de Mallorca, 05/06/1977.

${ }^{25}$ www.infoelectoral.mir.es.

${ }^{26}$ Total de votos a candidatura: 270,700, 82\% de participación. UCD: Unión de Centro Democrático; PSOE: Partido Socialista Obrero Español, AP: Federación de Partidos Alianza Popular; PSP-US: Partido Socialista Popular-Unidad Socialista; PCIB: Partido Comunista de les Illes Balears-Partido Comunista de España; UAB: Unió Autonomista; UDIB: Unió Democràtica de les Illes Balears; FDI: Frente Democrático de Izquierdas; RES: Reforma Social Española; AET: Agrupación Electoral de Trabajadores; CJA: Asociación Círculos José Antonio. 
Sin embargo, al no conseguir los objetivos marcados -que eran obtener representación en el Congreso de los Diputados e incidir en el debate autonómico y constitucional- la formación se disolvió, desapareciendo durante un quinquenio cualquier expresión organizada del mallorquinismo centrista en Baleares. En este sentido Adan (2015: 21) afirma:

“(...) La Unió Autonomista desapareció víctima de las deudas y de la huida de su líder, Josep Melià, a Madrid, quien, tras un periodo de reflexión, aceptó la oferta de su amigo Adolfo Suárez para ser director general de Relaciones Informativas del Gobierno y esperar a mejores momentos para volver a la política isleña. Había fracasado pues el único intento por articular un partido de centro derecha con tintes nacionalistas, y no es que no existiera el nicho sociológico para su desarrollo, pero la fuga de este sentimiento hacia la UCD era por aquel entonces mucho más segura en términos de éxito electoral (...)."

Ante la disolución de la UA, buena parte del espacio electoral del mallorquinismo de centro-derecha fue ocupado por la UCD de Suárez. ${ }^{27}$ Este partido, consiguió en las islas un $40 \%$ más de apoyos que la media estatal. En su conjunto, el centro-derecha sumaba en Baleares el $60 \%$ de los votos, capitalizado por los centristas. De esta forma en octubre de ese mismo año Jeroni Albertí (1927), máximo líder del partido en Baleares, afirmaba al Diario de Mallorca "la mayor responsabilidad de mi vida es hacer el Estatuto que Baleares necesita." ${ }^{28}$ De igual manera, cuando el proyecto de Estatut de Autonomía abandonó la via rápida del artículo 151 en favor de los preceptos recogidos en el artículo 143 de la Constitución, Albertí y otros dirigentes centristas expresaron su disconformidad con la decisión. ${ }^{29}$

\section{Las primeras elecciones autonómicas (1983)}

Solo teniendo en cuenta la evolución regionalista de la UCD balear puede entenderse la inexistencia de candidaturas de centro-derecha mallorquinistas en las elecciones legislativas y preautonómicas de 1979 y 1982 y el posterior surgimiento de Unió Mallorquina (UM). UM fue impulsada por Albertî ${ }^{30}$ y otros dirigentes y cuadros de la UCD en 1982, en plena descomposición del partido de Suárez. Este proceso fue singular para los territorios de habla catalana, ya

${ }^{27}$ El País 23/07/2000.

${ }^{28}$ Diario de Mallorca 14/07/1978.

${ }^{29}$ El País 06/02/1982.

${ }^{30}$ Jeroni Albertí es empresario. Líder de la patronal ASIMA, fue dirigente de UCD Balears, senador, presidente del Consell General Interinsular (1978-1982), órgano preautonómico. En 1983 fundó UM. Presidente del Parlament Balear (1987-1991) i del Consell Insular de Mallorca (1979-1982, 1983-1987). 
que en Catalunya buena parte de la UCD se incorporó al proyecto de Jordi Pujol; mientras que en el País Valenciano, el partido de Suárez apoyó el discurso anti-catalanista y anti-nacionalista (blaverismo) con el fin, entre otras cosas, de marcar un perfil propio y diferenciado de la izquierda, que controlaba el gobierno regional (Montés, 2004).

De esta forma en setiembre de ese año Albertí dimitía como presidente de la institución preautonómica (El Consell General Interinsular) y de UCD, para impulsar una nueva formación regionalista de centro, con el apoyo de buena parte del partido a nivel insular. ${ }^{31}$ En febrero, ante 2000 personas, el partido era presentado como un centro regionalista liberal con "vocación balear, española y europea". ${ }^{32}$ En ese momento, la principal figura del nacionalismo de centro, Melià, decidió permanecer junto a Suárez, de quien era amigo, impulsando en Baleares el CDS. Un intento de alianza entre UM y el CDS fracasó en enero del año siguiente. ${ }^{33}$

En marzo de 1983 se aprobó el Estatut que, con limitadas competencias, establecía unas instituciones de autogobierno. Ese mismo mes se celebró el Congreso fundacional de UM, con Albertí como presidente y Pere Morey como secretario general. Para mayo se convocaron elecciones municipales y autonómicas.

En estas elecciones UM y especialmente, Albertí, recibieron fuerte cobertura mediática, sobre todo del Diario de Mallorca (Adán; Payeras, 2015). La formación concurriría en Mallorca junto al pequeño Partido Democrático Liberal (PDL), de ámbito estatal, que en Eivissa era su referente, y en Menorca con la Candidatura Independent de Menorca (CIM), que se había gestado en esa isla al margen de los restos de UCD. Contaba con 20 millones de pesetas para realizar la campaña, frente a los 30 de AP y los 14 del PSOE. En este contexto, Albertí afirmó que "Podemos gobernar si somos el partido no socialista más votado." ${ }^{34}$ UM tenía que competir, por un lado, contra AP-PDP-UL, que con el hundimiento de la UCD se había convertido en la principal fuerza conservadora del archipiélago y del Estado. Por otro, UM también competía por el espacio centrista que quería ocupar el pequeño CDS así como con el PSOE, que consideraba que el partido de Albertí no tenía que ser necesariamente un aliado natural de las formaciones progresistas (Adán; Payeras, 2015).

No puede entenderse el mallorquinismo de centro-derecha en 1983 sin explicar brevemente la figura de Gabriel Cañellas, candidato de AP. ${ }^{35}$ Quién

${ }^{31}$ Última Hora, 20/08/1982.

${ }^{32}$ Diario de Mallorca 10/02/1983.

33 Íbid.

${ }^{34}$ Diario de Mallorca 04/05/1983.

${ }^{35}$ Gabriel Cañellas (1941), empresario. Fue presidente de la CAIB entre 1983 y 1995 por Alianza Popular y el Partido Popular. 
fuese el máximo dirigente de esta formación hasta 1995 estableció una forma de hacer política que se ha convenido a definir como cañellismo. Esta ideología se caracterizaría por aceptar el marco sociocultural y político del régimen constitucional de 1978, pero moviéndose, en mayor o menor medida, en un regionalismo folklórico que no cuestiona el modelo de estado. Así, Cañellas, potenció una actitud paternalista hacia sectores sociales como el nacionalismo. Esta actitud se concretó en ciertas concesiones a la oposición, como la Ley de Normalización Lingüística (1986), aprobada por consenso en el Parlament Balear. Esta tendencia conectaría con aquellos aspectos del mallorquinismo asumibles por buena parte de las clases dominantes (Jordà, 2014).

Tampoco puede entenderse la evolución del mallorquinismo durante estos años sin explicar brevemente el Gonellismo. Esta tendencia ideológica oscila entre la crítica a la excesiva influencia estandarizadora de la lengua catalana de Mallorca hasta a la negación que el habla mallorquina y la catalana forman parte del mismo sistema lingüístico. Este movimiento tuvo su mayor expresión durante los últimos años del franquismo y durante el debate sobre cuál tenía que ser la denominación de la lengua cooficial de Baleares en el Estatut d'Autonomia de les Illes Balears -si balear o catalán-. Según los pocos estudios sobre el tema, el gonellisme defendería el alejamiento de la sociedad mallorquina del proyecto lingüístico y político catalán para mantenerla, de este modo, en el statu quo actual alineada con el proyecto español. Este movimiento se habría alineado en su gran mayoría con tendencias ideológicas conservadoras y de extrema derecha (Calaforra y Moranta, 2005).

Unió Mallorquina obtuvo en 1983 46,915 votos, un 18\% en Mallorca y 6 diputados, un éxito que le permitía ejercer de partido bisagra en el Parlament Balear, dónde AP-PDP-PL y PSOE empataron a 21 escaños. El partido obtuvo únicamente el 9\% de los votos en Palma, pero en los pueblos de la isla consiguió grandes resultados, como en Inca (37\%), Calviá (25\%) y Manacor (21\%), amén de registros por encima del 50\% en Mancor, Banyalbufar, Costitx, Deià, Santa Eugènia, Campos y Escorca. ${ }^{36} \mathrm{~A}$ nivel local, UM se hizo con 136 regidores. En Menorca, la CIM consiguió un escaño y en Eivissa el PDL otro. Los 8 diputados electos formaron el Grupo Parlamentario Regionalista (GPR) en la primera legislatura de la cámara autonómica balear (Tablas 2 y 3). ${ }^{37}$

${ }^{36}$ www.infoelectoral.mir.es

${ }^{37}$ Total de votos a candidatura: 260,231, 65.05\% de participación. PSOE: Partido Socialista Obrero Español, AP-PDP-UL: Federación de Partidos Alianza Popular-Partido Demócrata Popular-Unión Liberal; PSM: Partit Socialista de Mallorca-Partit Socialista de les Illes; PCIB: Partido Comunista de les Illes Balears-Partido Comunista de España; UM: Coalició Unió Mallorquina; Centro Democrático y Social (CDS), a nivel local, hubo un 12.3\% de votos a candidaturas independientes de carácter local, con 134 regidores. 
Tabla 2. Resultados elecciones autonómicas en Mallorca (1983) (30 diputados elegidos de 54)

\begin{tabular}{c|c|c|c}
\hline Partido & Voto & $\%$ & Diputados \\
\hline PSOE & 88771 & 34.85 & 11 \\
\hline AP-PDP-UL & 87893 & 34.51 & 11 \\
\hline UM & 46915 & 18.42 & 6 \\
\hline PSM & 16979 & 6.67 & 2 \\
\hline PCIB & 6525 & 2.6 & \\
\hline CDS & 6101 & 2.4 & \\
\hline
\end{tabular}

Fuente: www.infoelectoral.mir.es

Tabla 3. Resultados elecciones municipales en Baleares (1983)

\begin{tabular}{c|c|c|c}
\hline Partido & Voto & $\%$ & Regidores \\
\hline PSOE & 105207 & 33.8 & 203 \\
\hline AP-PDP-UL & 104257 & 33.5 & 258 \\
\hline UM & 27996 & 9.0 & 136 \\
\hline PSM & 14837 & 4.7 & 47 \\
\hline PCIB & 7256 & 2.3 & 4 \\
\hline CDS & 5090 & 1.6 & 8 \\
\hline
\end{tabular}

Fuente: www.infoelectoral.mir.es

El GPR decantó el primer gobierno autonómico hacía el candidato popular, Cañellas, consiguiendo a cambio que Albertí se hiciese con la presidencia del Consell de Mallorca. Este primer pacto fue firmado en el despacho de Carlos March en Madrid, y para su gestación fueron decisivas las intervenciones de los poderes fácticos vinculados a la Mallorca conservadora. El mencionado March (de la Banca March), Gabriel Escarrer (de los hoteles Sol Melià), Francesc Albertí (presidente de la confedereación empresarial) o Pau Català (presidente de la cámara de comercio) son algunos de los prohombres que ayudaron a fraguar el acuerdo. Jeroni Albertí declaró años después que había actuado bajo presión. La importancia del pacto, en las condiciones que fue firmado, es que estableció una alianza entre todo el centroderecha que marcó toda una serie de alianzas conservadoras que perdurarían durante toda una década (Payeras, 1989). 


\section{Conclusiones}

A lo largo de esta investigación se han analizado las principales características, evolución histórica y social de los diferentes movimientos de centro-derecha autonomistas, regionalistas e insularistas de Mallorca. Así, hemos podido observar que desde sus orígenes hasta el Franquismo, el mallorquinismo político fue en su gran mayoría un proyecto regeneracionista, católico y liberalconservador. Sus máximas figuras de la época, como Miquel dels Sants Oliver, Joan Estelrich, Guillem Forteza, e incluso Josep Melià, se enmarcarían, con matices, en este espectro ideológico. Es más, hasta 1976, con el surgimiento del PSM, no habría existido ningún partido mallorquinista de izquierdas en Baleares.

Asimismo, han sido observadas dos tendencias convergentes en el seno del mallorquinismo de centro-derecha. Por un lado, hay una línea identificada con el catalanismo moderado, no independentista, europeísta, democristiano y liberal, que tendría a los proyectos de la Lliga Regionalista primero, y de CDC después, como referentes. Nos referimos al Centre Autonomista (19301936) de la II República, al pensamiento de opinión congregado en torno a la figura de Josep Melià y a partidos como la Unió Autonomista (1976-1977). Esta tendencia surgiría, a nuestro parecer, de unas clases medias liberales y pequeñoburguesas que no se sienten identificadas con partidos de ámbito estatal y quieren impulsar proyectos de obediencia balear. Estas personas creerían que solo una fuerza política de obediencia autóctona podría defender con efectividad sus intereses económicos y culturales como grupo, mientras que los partidos de ámbito estatal estarían sometidos a dinámicas perjudiciales para las Islas. Sin embargo, el poco peso en términos sociales de estos segmentos de la sociedad, así como el predominio en Mallorca de un modelo de relaciones agrario y caciquil, harían que estos sectores no tuviesen la importancia que tuvieron en Catalunya. Además, no hay que olvidar que parte de los profesionales liberales y de los pequeños comerciantes e industriales encontró su espacio electoral en el republicanismo federal moderado, y en el PSM después.

Por otro lado, existiría una corriente de opinión que se podría enmarcar dentro de un regionalismo isleño -en el sentido amplio del término-. Sería un movimiento sensible a la promoción de la lengua, cultura y tradiciones propias de la isla, pero que no pondría en duda el statu quo ni el concepto vigente de España. Este movimiento conectaría en cierta forma con la estética y valores que desprenden los sectores más moderados de la Escola Mallorquina. Correspondería a proyectos como el Partit Regionalista de Mallorca (1930-1936) o la primigenia UM (1983). Esta visión del mallorquinismo, en buena parte desproblematizadora, conciliaría la visión de Estado-Nación de España con las sin- 
gularidades culturales de la isla, acercando así el proyecto de España a las clases populares. Este mallorquinismo, como diría Archilés para el caso valenciano (Archilés, 2006), sería una herramienta que permitiría conciliar las identidades culturales de cada región con una identidad española nacional.

Esta visión del regionalismo tendría cierto éxito al encajar mejor con los valores católicos y folklorizantes de la ruralía isleña, conservadora y caciquil, que el catalanismo del Centre Autonomista o la UA. Las diferencias ideológicas entre este grupo y sectores regionalistas de partidos de centro-derecha de ámbito estatal no siempre estarían claras y las fronteras entre unos y otros serían difusas, como en el caso del cañellismo. De esta forma, sería posible que este mallorquinismo fuese utilizado más como un elemento diferenciador de una facción política dentro de la derecha que como elemento central de su discurso. Solo así se entenderían los vasos comunicantes entre estos sectores regionalistas y los partidos de derechas de ámbito estatal, que tendrían suficiente capacidad de cooptación, seguramente al ser espacios más transversales, de mayor incidencia política y control de poder.

Sin embargo, hay que destacar que ambas facciones del mallorquinismo de centro-derecha han tendido a convergir. Así, la primera -más catalanistacontaría con más apoyos intelectuales, mientras que la segunda contaría con una mayor base electoral.

De igual forma, estos movimientos han intentado formar recurrentemente coaliciones de ámbito estatal con otras formaciones que, desde ópticas moderadas, intentaban reformar España o tenían una visión de ella más respetuosa con las diferentes culturas que la forman. Por ejemplo, el PRM apoyó a Cambó en 1931 y UM se presentó en 1983 con el PDL. Ha sido en el seno de estas coaliciones cuando el mallorquinismo de centro-derecha ha obtenido sus mayores cuotas de poder, si bien su perfil político se ha visto desdibujado al colaborar con proyectos estatales. El hecho de que el mallorquinismo sea, en buena medida a lo largo del siglo XIX y XX un movimiento pactista que busca sobre todo la promoción y protección de la lengua y cultura propias de Mallorca, habría facilitado la entente con fuerzas de ámbito estatal, tanto a derecha como izquierda.

Respecto a los resultados electorales, las fuerzas políticas mallorquinistas no consiguieron obtener porcentajes significativos hasta la II República. Sin embargo, la coyuntura política, la escalada de violencia y el advenimiento de la Guerra Civil hizo que el PRM y el Centre Autonomista actuasen de forma connivente con las fuerzas que apoyaron a los golpistas, como también lo hicieron en Catalunya sectores de la Lliga. De esta forma el regionalismo de centro-derecha priorizó el "orden" y la lucha contra el anticlericalismo, aunque 
eso supusiese aliarse con fuerzas políticas nacionalistas españolas. Posteriormente, durante la Transición, el mallorquinismo moderado de centro-derecha no consolidó una base electoral importante, obteniendo mayor eco en el seno de formaciones como la UCD y el CDS, dónde constituyeron corrientes regionalistas que llegaron a controlar el partido.

Con la disolución de UCD y el surgimiento de UM, se creó un partido regionalista que se hizo con el 18\% de los votos en Mallorca en 1983. Este buen resultado ha de entenderse en parte por el paso a esta formación de buena parte de los cuadros de la extinta UCD, como el propio Albertí, más que por la consolidación de una ideología regionalista entre la población. A nuestro entender, UM aspiraba a convirtiese en una nueva plataforma de poder en Baleares, cosa que no sucedió, al ocupar este espacio AP. Sin embargo, no ha de menospreciarse la capacidad de influencia del regionalismo de centro-derecha, que ha formado parte como corriente, en mayor o menor medida, de todos los proyectos políticos liberal-conservadores que han existido en las Islas y han ostentado el poder a lo largo del siglo XX.

En relación a los vínculos entre el catalanismo y el valencianismo político y el mallorquinismo conservador, hay que decir que han sido orgánicamente inexistentes. Sin embargo, los paralelismos entre la evolución histórica de unos y otros movimientos son más que evidentes, así como las influencias mutuas, con figuras intelectuales de peso importante en el Principado, como Joan Estelrich o Josep Melià. Así, los éxitos del catalanismo moderado obtenidos por la Lliga o CDC, habrían tenido siempre un eco balear de mayor o menor intensidad.

Respecto a las relaciones entre el mallorquinismo de centro-derecha y movimientos similares en otras islas, hay que decir que han existido, tácticamente y de forma puntual. Nos referimos, por ejemplo, a la unión electoral del Centro Constitucional (1931) o a la creación del GPR en 1983. Sin embargo, el poco peso del nacionalismo y/o el regionalismo de centro-derecha en las otras islas han hecho imposible que surgiesen sinergias mayores.

Por último hay que decir que la extensión temporal del presente estudio, si bien permite obtener una visión de conjunto, ha supuesto un ejercicio de síntesis. En futuras investigaciones sería interesante ampliar las fuentes consultadas, más allá de la prensa. Nos referimos, por ejemplo, a la posible información contenida en documentación, resoluciones y ponencias internas de partidos y asociaciones mallorquinistas. Así mismo, también sería conveniente utilizar más fuentes bibliográficas, como los Dietaris de Joan Estelrich o las obras de figuras anticatalanistas, como los hermanos escritores Miquel i Josep Villalonga, Lluis Alemany, presidente de la Diputación Balear a principios del siglo XX, o Josep Zaforteza, dirigente de la UCD durante la Transición. 


\section{Bibliografía}

ADAN, Gonzalo; PAYERAS, Miquel (2015). El complejo comportamiento del voto en Baleares, Palma: In itinere.

AMAT, Jordi (2015). El llarg procés: cultura i política a la Catalunya contemporània (1937-2014). Barcelona: Tusquets.

ARCHILÉS, Ferran (2006). Hacer región es hacer patria. La región en el imaginario de la nación espanyola de la Restauración, Ayer, 64, 121-147.

BILBENY, Norbert (1988). Eugeni d'Ors i la ideología del nocentisme. Barcelona: La Magrana.

BOBIO, Norberto (2000). Derecha e Izquierda, Madrid: Punto de Lectura.

CALAFORRA, Guillem; MORANTA, Sebastià (2005) Propostes i despropòsits: aspectes del gonellisme. Marges, Els: revista de llengua i literatura, 77, 51-73.

< http://www.raco.cat/index.php/Marges/article/view/142364>

DURAN, Miquel; MARIMON, Antoni (2004). Història de les Illes Balears. Del segle XVIII borbònic a la complexa contemporaneïtat. Barcelona: Edicions 62.

ESTELRICH, Joan (2015). El món d'ahir de Joan Estelrich: ditaris, cultura, i acció política. València: Universitat de València.

FERRÀ-PONS, Damià (1973). Avantguardisme plàstic a Mallorca, Lluc, 10, 34-91.

FERRER-FLÓREZ, Miquel (2002). Naixement i evolució del Carlisme a la Mallorca del segle XIX, Memòries de la Reial Acadèmia Mallorquina d'Estudis Genealògics, Heràldics i Històrics, 12, 234-245

< https://dialnet.unirioja.es/servlet/articulo? codigo=2671102>

FUSI, Juan Pablo; NIÑO, Antonio (1997) Vísperas del 98. Orígenes y antecedentes de la crisis del 98, Madrid: Biblioteca Nueva.

GINARD, David (2015). La repressió a les Balears durant la Guerra Civil. Palma: Documenta Balear.

GONZÁLEZ-VILALTA, A (2006). La nació imaginada. Els fonaments dels Països Catalans (1931-1939). Barcelona: Editorial Afers.

GUASCH, Maria. (1983). El Modernisme a Catalunya. Barcelona: Ajuntament de Barcelona.

GRAÑA, Isabel (2007). Els poetes de l'Escola Mallorquina i l'Associació per la Cultura de Mallorca. Palma: Lleonard Muntaner.

JORDÀ, Joan Pau (2014). Entre el desencanto y la necesaria renovación, Viento Sur, 142, 107-117 < http://vientosur.info/spip.php?article10862>

JORDÀ, Joan Pau; COLOM, Joan; MAYOL, Gabriel (2016). Somnis Compartits. La identitat mallorquina a debat. Palma: Documenta Balear.

LLOMPART, Josep Maria (1964). La literatura moderna a les Balears. Palma: Editorial Moll.

MARIMON, Antoni (2003). El nacionalisme a Mallorca: evolució històrica des dels orígens fins a l'actualitat. Palma: Editorial Baltar.

MARIMON, Antoni (2008). Sobre el nacionalisme a Mallorca (1890-1936), Cercles, revista d'història cultural, 11, 43-59. < http://dx.doi.org/10.1344/cercles2008.11.> 
MAS, Llorenç (2009). Antoni Maria Alcover (1962-1932), testimonis orals, mite i persona, Manacor: Institució Antoni $\mathrm{M}^{\mathrm{a}}$ Alcover.

MASSOT-I-MUNTANER, Josep (1978). Cultura i vida a Mallorca entre la guerra i la postguerra, 1930-1950, Barcelona: Biblioteca Serra d'Or.

MELIÀ, Josep (1977). La nació dels mallorquins. Barcelona: Selecta.

MIR, Gregori (1988). El nacionalisme de La Nostra Terra. Palma: Moll.

MIR, Gregori (1990). El Mallorquinisme polític (1840-1936). Palma: Moll.

MIR, Gregori (2006). Sobre nacionalistes i nacionalisme a Mallorca, Palma: Moll.

MONTÉS, Iranzo; (2014). Prensa y poder. Las Provincias, actor político central de la Transición valenciana. Historia y Comunicación Social, 19, 535-544.

OLAZÁBAL, Carlos María (2014). Negociaciones del PNV con Franco durante la Guerra Civil, Bilbao: Fundación Popular de Estudios Vascos.

OLIVER, Miquel dels Sants (1987 [1899]). La Qüestió Regional. Barcelona: La Magrana.

PABLO, Santiago; MEES, Ludger; RODRÍGUEZ, José Antonio. El péndulo patriótico. Historia del Partido Nacionalista Vasco, Barcelona: Crítica.

PAREDES, Javier. Historia de España contemporánea. Barcelona: Ariel.

PAYERAS, Miquel (1991). Deu anys de Cañellisme, El temps, 452, 76-82.

PEÑARRUBIA, Isabel (1991). Els partits polítics a Mallorca davant el caciquisme i la qüestió nacional. Barcelona: Abadia de Montserrat.

PIÑA, Roman (2016). Ser de los nuestros, Palma: Slooper.

PONS, Damià (1978). L'Espurna: un projecte d'actuació política d'un sector de la intelectualitat mallorquina (1909). Mayurqa, 18, 93-99

<http://www.raco.cat/index.php/Mayurqa/article/view/118640>

PONS, Damià (2002). El Jonc i l'Aritja: País, Cultura, Política, Palma: Documenta Balear.

PONS, Damià (2002). Entre l'afirmació individualista i la desfeta col lectiva: escriptors $i$ idees en la Mallorca del primer terç del segle XX, Barcelona: Abadia de Montserrat.

RIQUER, Borja de, (1977). Lliga Regionalista: la burgesía catalana i nacionalisme (18981904), Barcelona: Edicions 62.

RIQUER, Borja de (2000). Escolta Espanya. La cuestión catalana en época liberal. Madrid: Marcial Pons Història.

SERRA-BUSQUETS, Sebastià (1980). La Veu de Mallorca. Una publicació nacionalista entre el 1900 i 1931, Mayurqa, 20, 293-218.

SORRIBAS, Sebastià (1989). La Reinaixença. Barcelona: Barcanova.

TERMES, Josep (2000). Història del catalanisme fins 1923, Barcelona: Pòrtic.

VALLVERDÚ, Robert (2008). La Metamorfosi del carlisme català: del "Déu, Pàtria i Rei" a l'Assemblea de Catalunya (1936-1975)”. Barcelona: Abadía de Montserrat. 